\title{
Pengaruh Jurusan, Biaya dan Kualitas terhadap Keputusan Siswa Untuk Masuk SMK Negeri 2 Batanghari
}

\author{
${ }^{1}$ Ahmad Fithoni, ${ }^{2}$ Zazili \\ ${ }^{1,2}$ Sekolah Tinggi Ilmu Ekonomi Graha Karya Muara Bulian \\ Correspondence email: ahmadfithoni69@gmail.com,zazili@gmail.com
}

\begin{abstract}
This study aims to determine the Effect of Department, Cost and Quality on Student Decisions to enter Kujuruan Middle School (SMK). This research is descriptive quantitative with the number of respondents as many as 110 people from students of SMK Negeri 2 Batanghari. The analysis used is multiple regression, partial test ( $t$ test), simultaneous test ( $f$ test), and determination test (R2). The results showed that the most dominant independent variable or a positive influence was the Cost variable (X2) with tcount (10,969)> t table (1,65936). For F Test it is known that Fcount $=101.212>$ Ftable $=2.69$ This means that together the Department, Cost and Quality influence the Student's Decision to enter SMK Negeri 2 Batanghari because the calculated $f$ value of 101.212 is greater than the f table 2.69 (101.212 > 2.69). While seen from the coefficient of determination. Department, Cost and Quality influence the Decision of Students to enter SMK Negeri 2 Batanghari by 73.4\% and the remaining $2.66 \%$ is influenced by other factors not examined in this study.
\end{abstract}

Keywords: Department, Cost, Quality and Student Decision.

\section{PENDAHULUAN}

Dalam arti luas, Pendidikan berkaitan dengan upaya untuk mengembangkan aspek kehidupan seseorang baik berupa pandangan hidup, sikap hidup dan keterampilan hidup. Karena pendidikan merupakan bagian integral pembangunan yang diarahkan untuk mengembangkan sumber daya manusia yang mampu menjawab tuntutan kompetensi dalam penerapan keterampilan hidup (life skill) yang sangat dibutuhkan oleh bangsa indonesia yang saat ini terus membangun dalam sektor pembangunan khususnya sektor industri. Sebagai negara berkembang yang sedang membangun, Indonesia tentunya sangat membutuhkan tersedianya tenaga kerja yang terampil di berbagai bidang keahlian. Salah satu wujud usaha pemerintah dalam bidang pendidikan yaitu dengan membuat kebijakan dengan mendirikan beberapa sekolah kejuruan yang lulusannya dipersiapkan untuk menjadi tenaga kerja terampil dan siap pakai yang sesuai dengan perkembangan teknologi dan perubahan pasar kerja. Dengan demikian secara signifikan diharapkan dapat memperbaiki atau mengurangi jumlah pengangguran di Indonesia.

Perkembangan Ilmu Pengetahuan dan Teknologi (IPTEK) yang semakin pesat menimbulkan berbagai perubahan di segala bidang kehidupan, salah satunya adalah perubahan dalam dunia kerja. Tuntutan dari dunia kerjasemakin berat. Hal tersebut merupakan beberapa persyaratan yang diperlukan untuk dapat di terima di dunia kerja, selain persyaratan-persyaratan khusus lainnya yang disesuaikan dengan jenis pekerjaan yang ditawarkan.Tuntutan dari dunia kerja yang semakin berat, di tambah dengan banyaknya pencari kerja yang tidak sebanding dengan jumlah lapangan kerja yang tersedia di masyarakat mengakibatkan persaingan dalam mencari pekerjaan semakin berat. Dalam hal ini belajar keras serta etos kerja yang tinggi menjadi modal utama yang harus di miliki oleh seseorang untuk memenangkan persaingan dunia kerja. Oleh karena itu, sistem belajar dan pembelajaran yang mengacu pada pembentukan manusia cerdas, kreatif dan bermoral menjadi sangat mendesak (Tim MKDK UNNES, 2000). Dalam menghadapi era globalisasi dan pasar bebas saat ini, kemungkinan adanya peningkatan jumlah tenaga kerja yang dibutuhkan oleh industri. Oleh karena itu, untuk bisa memenuhi kebutuhan tenaga kerja yang memiliki keterampilan dan kualitas yang telah terdidik perlu untuk ditingkatkan lagi. SMK secara tidak langsung memiliki peranan yang sangat besar untuk meningkatkan kualitas, keterampilan dan kemampuan siswa dalam menguasai ilmu teknologi dan keteknikan, Salah satu cara yang bisa dilakukan adalah dengan benar-benar melakukan seleksi pada siswa yang akan masuk ke SMK. Undang-undang sistem pendidikan nasional pasal 3 tentang tujuan pendidikan dan penjelasan pasal 15 tahun 2003 menyebutkan bahwa pendidikan kejuruan merupakan pendidikan menengah yang mempersiapkan peserta didik terutama bekerja dalam bidang tertentu. Sekolah menengah kejuruan (SMK) merupakan pendidikan menengah dan jalur pendidikan formal, SMK mempunyai tujuan menyiapkan siswa untuk memasuki lapangan kerja serta mengembangkan sikap profesional dan menyiapkan tenaga kerja tingkat menengah untuk mengisi kebutuhan dunia usaha dan industri pada saat ini maupun masa akan datang.

Orientasi Sekolah Menengah Kejuruan adalah : (1) membekali kompetensi/ketrampilan siswa untuk memenuhi kebutuhan pasar kerja di dunia usaha/dunia industry, (2) membekali kompetensi/ketrampilan siswa untuk hidup mandiri mengembangkan wirausaha, menciptakan lapangan kerja, (3) membekali kompetensi/ketrampilan dan 
kecakapan akademis siswa untuk memberikan peluang melanjutkan ke tingkat pendidikan yang lebih tinggi. Preferensi bersekolah adalah keinginan atau kecenderungan seseorang untuk bersekolah atau tidak bersekolah di suatu sekolah yang dipengaruhi oleh faktor-faktor tertentu. Preferensi masyarakat dalam memilih sekolah sangat bervariasi, karena setiap individu mempunyai keinginan berbeda-beda dalam memilih sekolah.

Persepsi berkaitan dengan cara mendapatkan pengetahuan khusus tentang suatu fenomena pada saat tertentu dan mencakup pula pada aspek kognitif/pengetahuan. Menurut tulisanterkini.com : Persepsi seseorang terhadap suatu objek dapat berbeda dengan orang lain. Perbedaan tersebut dipengaruhi oleh berbagai faktor. Cara kita mempersepsikan situasi sekarang tidak bisa terlepas dari adanya pengalaman sensoris terdahulu. Kalau pengalaman terdahulu itu sering muncul, maka reaksi selalu menjadi kebiasaan secara ilmiah benar mengingat respon-respon perceptual yang ditunjukkannya. Oleh karena itu, apa yang dipersepsikan pada suatu waktu tertentu akan tergantung bukan saja pada stimulusnya sendiri, tetapi juga pada latar belakang beradanya stimulus lainnya. Lebih jauh dikatakan terdapat tiga faktor utama yang mempengaruhi persepsi secara umum pada seseorang. Faktor tersebut adalah karakteristik individu, kebutuhan dan faktor situasi. Serta tiga faktor yang mempengaruhi persepsi terhadap orang lain yaitu (a) keadaan stimulus dari orang yang dipersepsi, (b) situasi sosial tempat mana stimulus berada, (c) keadaan atau karakteristik dari orang yang mempersepsi (perseptor).

Pengambilan Keputusan, merupakan suatu tindakan yang menentukan hasil dalam memecahkan masalah dengan memilih suatu jalur tindakan di antara beberapa alternatif yang ada melalui suatu proses mental dan berfikir logis dan juga mempertimbangkan semua pilihan alternatif yang ada yang mempunyai pengaruh negatif atau positif.(http://41816010007.blog.mercubuana.ac.id/?p= 9)

Kurangnya informasi akan jurusan dan lapangan kerja yang akan dihadapi oleh remaja ketika mereka lulus menambah kekhawatiran siswa dalam pengambilan keputusan. Menurut Ana Nurhayana, beberapa hal yang perlu diperhatikan oleh seorang siswa dalam memilih pendidikan lanjut adalah : Bakat, Minat, Kamampuan, Dorongan Orang Tua, guru dan teman dan faktor informasi karir dan dunia kerja. (http://budiana2014.blogspot.com/2015/10/indikatorpemilihan-studi-lanjut-ke-sma.html) lebih jauh beliau membagi indikator pemilihan studi lanjut dalam dua kategori yaitu indikator yang bersumber dari siswa dan dari sekolah tujuan, yaitu : a. Indikator yang bersumber dari siswa terdiri atas : 1) Minat; 2) Bakat; 3) Cita-cita; 4) Kemampuan; 5) Prospek siswa dan 6) Dorongan orang tua, guru dan Teman. b. Indikator berdasarkan faktor dari sekolah tujuan, meliputi : 1) Reputasi sekolah; 2) Status akreditasi sekolah; 3) Fasilitas sekolah; 4) biaya sekolah; dan 5) Jurusan yang ada disekolah lanjutan. Sementara ahmad chan (http://ahmadsayipulloh9gkece.blogspot.com

/2014/03/memilih-sekolah-lanjutan-setelah-

lulus_7.html) menyebutkan Beberapa hal yang perlu diperhatikan dalam menentukan sekolah yang sesuai dengan orientasi siswa dimasa depan atau dari sudut pandang adalah : Minat, biaya dan Prospek. Sedangkan ditinjau dari Faktor esternal, dalam memilih sekolah, perlu untuk memperhatikan beberapa hal yaitu : Refutasi, status akreditasi dan fasilitas pendidikan.

Karena perkembangan ilmu pengetahuan dan teknologi yang begitu cepat, sedangkan sarana dan prasarana sekolah yang minim masih menjadi penyebab utama terjadinya kurang sinkron dengan sarana yang dimiliki oleh industri. Akibatnya ketika mereka berada di industri yang sesungguhnya harus belajar dari awal kembali. Oleh karena itu pengelola SMK harus meningkatkan sarana dan prasarana praktek maupun sarana pendukung pembelajaran lainnya agar benarbenar bisa dihasilkan siswa lulusan yang kompeten dan sesuai dengan tuntutan dunia usaha / industri. Tingkat mutu suatu SMK tidak hanya dilihat dari tingkat lulusan siswa yang tinggi dalam ujian nasional maupun ujian akhir sekolah, tetapi yang sangat penting adalah Suatu SMK mampu menyelengarakan proses pendidikan yang bermutu dan menghasilkan lulusan yang siap bekerja serta diserap dengan baik oleh dunia industri. Program pembangunan citra positif SMK adalah untuk meningkatkan image positif di mata masyarakat umum, orang tua dan perusahaan penerimaan lulusan SMK. Meningkatkan rasa kebanggaan memasuki SMK bagi lulusan SMP, serta menciptakan rasa percaya diri bagi lulusan SMK untuk memasuki dunia usaha/dunia industri maupun menjadi wirausahawan mandiri. Kualitas SMK yang bermutu dapat meningkatkan citra SMK dimata masyarakat dan sebaliknya citra SMK yang mutunya kurang baik dapat menimbulkan citra SMK yang kurang baik. Citra SMK yang baik dapat menjadi daya tarik minat masyarakat atau lulusan SMP untuk melanjutkan ke SMK. Maka dari itu para lulusan SMK mempunyai peran penting dalam pembentukan citra SMK dan berperan penting pula dalam menarik minat SMP untuk melanjutkan ke SMK. Siswa SMK diharuskan untuk melakukan praktik menguasai setiap teknik keahlian sehingga mereka berpengalaman dan siap untuk langsung memasuki dunia kerja. Sehingga bagi Siswa SMP yang tidak memiliki kemampuan ekonomi yang kuat SMK adalah pilihan terbaik untuk melajutkan pendidikan.

Namun tidak menutup kemungkinan juga para lulusan SMK dapat melajutkan pendidikan yang lebih tinggi lagi. Saat ini banyak SMK yang bertaraf internasional untuk menghadap persaingan era globalisasi. Citra SMK diharapkan mampu mengubah 
pola pandang masyarakat terhadap SMK. Citra SMK yang positif dapat mendorong masyarakat menerima dengan baik para lulusan SMK. Penghasilan orang tua juga menentukan alokasi dana untuk anaknya, Kekayaan pribadi saat ini juga dikaitkan dengan kemampuan untuk memenuhi biaya pendidikan dan melalui mekanisme ini, kendala keuangan diyakini secara langsung membatasi kesempatan pendidikan yang lebih tinggi dari sosial ekonomi kurang beruntung. Dengan perekonomian yang semakin maju, persainganpun semakin ketat. Dengan demikian siswa berpikir bahwa dengan melanjutkan sekolah ke SMK maka bisa langsung kerja dan membuka lapangan kerja setelah mendapatkan keterampilan dari sekolah. Sehingga jurusan yang diinginkan, biaya yang murah dan kualitas sekolah yang baik menjadi alternatif untuk masuk ke sekolah SMK.

Berdasarkan uraian di atas, maka tujuan penelitian ini adalah untuk mengetahui pengaruh jurusan, biaya dan kualitas terhadap keputusan siswa untuk masuk SMKN 2 Batanghari dengan asusmsi awal yang dituangkan dalam hipotesis penelitian bahwa $\mathrm{H}_{\mathrm{o}}$ : Jurusan, Biaya dan Kualitas tidak berpengaruh terhadap Keputusan Siswa untuk masuk ke Sekolah Menengah Kejuruan dan $\mathrm{H}_{\mathrm{a}}$ : Jurusan, Biaya dan Kualitas berpengaruh terhadap Keputusan Siswa untuk masuk ke Sekolah Menengah Kejuruan.

\section{METODE PENELITIAN}

Metode penelitian yang digunakan dalam penelitian ini adalah metode asosiatif yang bertujuan untuk mengetahui pengaruh atau hubungan antara dua atau lebih variabel.

\section{Variabel Penelitian}

Variabel adalah suatu atribut atau sifat atau nilai dari orang, objek, atau kegiatan yang mempunyai variasi tertentu yang ditetapkan oleh peneliti untuk di pelajari dan ditarik kesimpulannya (Sugiyono 2004). Penilitian ini menggunakan dua variabel yaitu : Variabel dependen adalah variabel yang menjadi pusat perhatian utama peneliti. Hakekat sebuah masalah mudah terlihat dengan mengenali berbagai variabel dependen yang digunakan dalam sebuah model. Variabilitas dari atau atas faktor inilah yang berusaha untuk di jelaskan oleh seorang peneliti (Ferdinand, 2006). Dalam penelitian ini yang menjadi keputusan siswa adalah : keputusan siswa untuk masuk SMK N 2 Batang Hari (Y) dan Variabel independen di lambangkan dengan (X) adalah variabel yang mempengaruhi variabel dependen, baik yang pengaruhnya positif maupun yang pengaruhnya negatif. Terdiri atas: Jurusan (X1), Biaya (X2) dan Kualitas (X3).

\section{Operasional Variabel}

Operasional Variabel adalah penentuan konstruk variabel dengan memberi arti atau menspesifikan kegiatan atau membenarkan suatu operasional sehingga dapat menjadi variabel yang dapat di ukur (indiarto dan supomo, 1999). Operasional variabel dalam penelitian ini meliputi variabel-variabel serta indikator sebagi berikut :

a. Variabel dependen (Y) dalam penelitian ini adalah keputusan siswa untuk masuk SMK N 2 Batang Hari yang dapat di asumsikan sebagai keputusan pemilihan jasa, yaitu keputusan siswa dan segala upaya yang di lakukan oleh siswa untuk melanjutkan studinya. Adapun indikator dari keputusan siswa tersebut adalah : a). Menentukan pilihan dengan mengumpulkan data /informasi; b). Memprioritaskan pilihan ; c). Keyakinan dalam memutuskan jasa ; dan d). Merekomendasikan jasa tersebut kepada pihak lain.

b. Variabel independen meliputi : Jurusan, Biaya dan Kualitas.

1) Pemilihan Jurusan bagi siswa SMA/Ma sederajat merupakan awal dari pemilihan karir ke depannya. Hal ini dikarenakan jurusan di SMA/Ma/SMK akan mengantarkan kita pada penjurusan studi lanjut sebelum akhirnya kita menentukan, memilih pekerjaan atau karir ke depannya. "Penjurusan diperkenalkan sebagai upaya untuk lebih mengarahkan siswa berdasarkan minat dan kemampuan akademiknya" (Bimo Walgito, 2010: 45). Di SMA, siswa-siswa yang mempunyai kemampuan sains dan ilmu eksakta yang baik, biasanya akan memilih jurusan IPA, dan yang memiliki minat pada sosial dan ekonomi akan memilih jurusan IPS, lalu yang gemar berbahasa akan memilih Bahasa, sedangkan di SMK siswa memilih jurusan sesuai dengan skill dan keterampilan yang mereka miliki atau ingin mereka kembangkan. Jurusan merupakan citra yang di bangun sekolah untuk mempengaruhi keputusn konsumen dalam melakukan pembelian. Adapun indikator dari jurusan terdiri atas : Bakat, Minat, Cita-cita, Kemampuan, Dorongan orang tua, guru dan teman serta Informasi karir dan dunia kerja.

2) Biaya merupakan keseluruhan pengorbanan finansial yang harus di keluarkan konsumen agar dapat menempuh pendidikan pada jurusan yang di pilih siswa di SMK N 2 Batang Hari. Adapun indikator dari variabel biaya meliputi : biaya pembangunan, biaya bulanan / semester dan beasiswa selama masa pendidikan.

3) Kualitas merupakan tingkat baik buruknya sesuatu (Kamus Besar Bahasa Indonesia). Selain itu kualitas menurut Goetsh \& Davis (1994). Kualitas merupakan suatu kondisi dinamis yang berhubungan dengan produk, layanan, manusia, proses, lingkungan yang memenuhi atau melebihi harapan. Adapun indikator dari kualitas sekolah : NEM (Nilai Evaluasi Murni) dan KKM ( Kriteria Ketuntasan Minimal). 


\section{Populasi dan Sampel}

Populasi adalah wilayah generalisasi yaang terdiri atas objek atau subjek, yang mempunyai kualitas dan karakteristik tertentu yang ditetapkan oleh peneliti untuk dipelajari dan kemudian ditarik kesimpulannya (Sugiyono, 2011). Populasi dalam penelitian ini adalah seluruh siswa SMK N 2 Batanghari dengan jumlah 549 peserta didik pada tahun ajaran 2017.

Selanjutnya dikatakan, bagian refresentif dari jumlah dan karakterisstik yang dimiliki oleh populasi (Sugiyono, 2011). Sampel dalam penelitian ini adalah sebagian dari siswa SMKN 2 Batang Hari. Sampel dalam penelitian ini adalah para siswa SMK Negeri 2 Batanghari yang masih aktif, artinya masih menempuh studi pada SMK Negeri 2 Batanghari.

Metode pengambilan sampel yang digunakan adalah Aksidental Sampling yaitu tehnik penentuan sampel berdasarkan kreteria atau pertimbangan tertentu (Usman rianse dan Abdi, 2012). Kreteria atau Pertimbangan yang digunakan dalam penentuan sampel dalam penelitian ini adalah menganggap bahwa seluruh populasi dianggap homogen dan dapat diwakili oleh siapa saja yang kebetulan menjadi sampel. Menurut Arikunto, besarnya sampel dalam penelitian apabila subyeknya kurang dari 100 maka lebih baik diambil semua sehingga penelitiannya merupakan penelitian populasi. Selanjutnya, jika jumlah subjeknya besar dapat diambil antara 10-15 \% atau 20-25 \% dari jumlah penelitian. Karena jumlah populasi penelitian ini 549 orang maka peneliti mengambil $20 \%$ dari jumlah Populasi yaitu sebanyak 110 orang siswa.

\section{Jenis dan Sumber Data}

Ada dua jenis data yang digunakan dalam penelitian ini, yaitu : Primer dan Sekunder. Data primer adalah data yang didapat dari sumber pertama atau sumber asli (langsung dari informan) (Usman rianse dan Abdi, 2012). Data primer dalam penelitian ini diperoleh dari hasil pengisian kueisioner oleh responden. Data primer dalam penelitian ini berupa identitas responden yang meliputi nama, usia, jenis kelamin, jurusan, serta jawaban dan alasan responden tentang variabel penelitian yaitu pengaruh jurusan, biaya dan kualitas terhadap keputusan siswa untuk melanjutkan studi di SMK Negeri 2 Batanghari. Sedangakan Data sekunder adalah data yang diambil dari sumber kedua atau bukan dari sumber aslinya, yang dapat berasal dari peneliti sebelumnya, lembaga pemerintah, lembaga swasta dan lain sebagainya (Usman rianse dan Abdi, 2012). Data sekunder dalam penelitian ini antara lain mencakup jumlah siswa, sejarah berdirinya SMK Negeri 2 Batanghari, dan hal lain yang berkaitan dengan penelitian.

\section{Metode Pengumpulan Data}

Metode pengumpulan data yang digunakan dalam penelitian ini adalah : a. Library Research (riset perpustakaan) yaitu dengan penelitian kepustakaan berupa publikasi sumber yang mempunyai referensi yang erat dengan objek penelitian dan penelaahan tersebut merupakan titik tolak untuk mengambil pengertian dan tentang permasalahan yang ada.

b. Field Research (Riset Lapangan) yaitu dengan melakukan penelitian lapangan, maksudnya yang dilakukan untuk mendapatkan gambaran yang terperinci dan dengan mencari dan memperoleh data dan informasi langsung dari yang berwenang dalam hubungannya dengan yang di bahas. Dengan riset lapangan, penulis memperokeh data langsung dari objek yang dituju dengan cara : Interview, yaitu dengan melakukan wawancara langsung, dengan pihak sekolah SMK Negeri 2 Batanghari, Observasi, yaitu dengan cara pengamatan langsung ke SMKN 2 Batanghari untuk mengetahui keadaan, situasi dan kondisi sekolah dan Kuesioner yaitu dengan cara menyebarkan daftar pertanyaan sebanyak jumlah sampel yang telah ditetapkan.

\section{Metode Analisis Data}

Agar suatu data yang dikumpulkan dapat bermanfaat, maka harus diolah dan dianalisis terlebih dahulu sehingga dapat dijadikan dasar pengambilan keputusan.Tujuan metode analisis data adalah untuk menginterprestasikan dan menarik kesimpulan dari sejumlah data yang terkumpul. Terdapat dua metode statistik dalam menganalisa data penelitian, yaitu metode kualitatif dan kuantitatif, dimana pada metode kualitatif dengan menggunakan pendekatan statistik deskriptif dan metode kuantitatif biasanya menggunakan statistika inferensia ( Sugiyono, 12011)

\section{Analisis data Kualitatif}

Analisis data kualitatif adalah bentuk analisis yang berdasarkan dari data yang dinyatakan dalam bentuk uraian. Data kualitatif ini merupakan data yang hanya dapat diukur secara langsung. Proses analisis kualitatif ini dilakukan dalam tahapan sebagai berikut: Pengeditan (Editing); Pemberian kode (Coding); Pemberian Skor (Scoring) dan Tabulasi (Tabulating). Untuk mengubah data yang bersifat kualitatif ke dalam bentuk kuantitatif. Dalam penelitian ini urutan pemberian skor menggunakan skala Likert dengan tingkatan : a. Skor 5 untuk jawaban Sangat Setuju (SS); b. Skor 4 untuk jawaban Setuju (S); c. Skor 3 utnuk jawaban Netral (N); d. Skor 2 untuk jawaban Tidak Setuju (TS) dan e.Skor 1 untuk jawaban Sangat Tidak Setuju (STS).

Untuk menganalisa masing-masing variable, baik independen (Pengaruh Jurusan/X1, Biaya/X2, Kualitas/X3) maupun variabel dependen (Keputusan Siswa/Y). Dimana untuk melakukan analisa akan dilakukan berdasarkan hasil pernyataan responden pada masing-masing pernyataan di setiap variabel. Untuk itu di buat kriteria pengklasifikasian yang mengacu pada 
ketentuan-ketentuan yang di kemukakan oleh husein umar (2001), dimana tentang skala diperoleh dengan rumus :

nilai maksimum-nilai minimum

Rs $=$

Jumlah kelas

Dimana :

Rs $=$ rentang skala

Nilai maksimum $=5$

Nilai minimum $=1$

Jumlah kelas $=5$

Dari rumus di atas, maka rentang skala dapat di hitung sebagai berikut

$R s=\frac{5-1}{5}=0,8$

Dengan rentang skala 0,8 maka skala numeriknya adalah sebagai berikut :

Tabel 1. Indek penilaian jawaban responden

\begin{tabular}{cc}
\hline Nilai Skor & Penilaian \\
\hline $1<\mathrm{x} \leq 1,8$ & Sangat Tidak Baik \\
$1,8<\mathrm{x} \leq 2,6$ & Tidak Baik \\
$2,6<\mathrm{x} \leq 3,4$ & Cukup Baik \\
$3,4<\mathrm{x} \leq 4,2$ & Baik \\
$4,2<\mathrm{x} \leq 5$ & Sangat Baik \\
\hline
\end{tabular}

Sumber : Suharsimi Arikunto (2010)

\section{Analisis Data Kuantitatif}

Analisis data kuantitatif adalah bantuk analisa yang menggunakan angka-angka dan perhitungan dengan metode statistic, maka data tersebut harus diklasifikasikan dalam kategori tertentu dengan menggunakan tebel-tebel tertentu. Adapun alat analisa yang digunakan yaitu uji validitas dan reliabilitas.

\section{Uji Validitas}

Uji validitas digunakan untuk mengukur sah atau valid tidaknya suatu kuesioner. Satu kuesioner dinyatakan valid jika pertanyaan pada kuesioner mampu mengungkapkan sesuatu yang akan diukur oleh kuesioner tersebut (Ghozali, 2009). Uji validitas ini dilakukan dengan cara melakukan korelasi antara score masing-masing butir pertanyaan dengan total score. Kuesioner dikatakan valid jika nilai $r$ hitung $>$ dari pada $r$ tabel dan sebaliknya kuesioner dikatakan tidak valid jika nilai $r$ hitung < hari $\mathrm{r}$ tabel dengan tingkat signifikasi sebesar 0,05.

\section{Uji Reliabilitas}

Uji reliabilitas digunakan untuk mengukur kuesioner yang merupakan indikator dari variabel.Kuesioner dikatakan reliabel atau handal jika masing-masing pertanyaan dijawab responden secara konsisten atau stabil dari waktu ke waktu.Suatu kuesioner dikatakan handal jika nilai Cronbach Alpha lebih besar dari 0,600 (Ghozali, 2009).

\section{Persamaan Regresi Linier Berganda}

Analisis yang digunakan dalam penelitian ini adalah analisis regresi linier berganda (multiple regression). Analisis regresi linier berganda digunakan untuk menganalisis pengaruh antara variabel independen (jurusan, biaya, dan kualitas) terhadap variabel dependen yaitu keputusan siswa. Rumus matematis dari regresi linier berganda yang digunakan dalam penelitian ini adalah :

$$
\begin{aligned}
& \mathrm{Y}=\mathrm{a}+\mathrm{b} 1 \mathrm{X} 1+\mathrm{b} 2 \mathrm{X} 2+\mathrm{b} 3 \mathrm{X} 3+\mathrm{e} \\
& \text { Keterangan : } \\
& \mathrm{Y}=\text { Keputusan siswa } \\
& \text { a } \quad=\text { Konstanta } \\
& \mathrm{b} 1, \mathrm{~b} 2, \mathrm{~b} 3=\text { Koefisien regresi } \\
& \mathrm{X} 1=\text { Jurusan } \\
& \mathrm{X} 2=\text { Biaya } \\
& \mathrm{X} 3=\text { Kualitas } \\
& \mathrm{e}=\text { error disturbances }
\end{aligned}
$$

\section{Pengujian Hipotesis \\ Uji t (Uji Parsial)}

Uji T digunakan untuk menguji signifikansi konstanta dari setiap variabel independen, apakah variabel jurusan (X1), biaya (X2), dan kualitas (X3) benar-benar berpengaruh secara parsial (terpisah) terhadap variabel dependennya yaitu keputusan siswa (Y). dengan Kriteria pengujian dengan tingkat signifikansi (a) $=0,05$ ditentukan sebagai berikut $: 1) . t$ hitung $<\mathrm{t}$ tabel, maka Ho diterima dan 2). $\mathrm{t}$ hitung $>\mathrm{t}$ tabel, maka Ho ditolak

\section{Uji F (Uji Simultan)}

Uji $F$ yaitu suatu uji untuk mengetahui variabel bebas yaitu Jurusan (X1), Biaya (X2), dan Kualitas (X3) secara bersama-sama berpengaruh terhadap variabel terikat yaitu keputusan siswa (Y). dengan Kriteria untuk menguji hipotesis dan tingkat kepercayaan sebesar 95\% atau taraf signifikansi sebesar 5\%, sebagai berikut : 1). Jika F hitung > F tabel, maka $\mathrm{H} 0$ ditolak, berarti masingmasing variabel bebas secara bersama-sama mempunyai pengaruh yang signifikan terhadap variabel terikat dan 2). Jika $\mathrm{F}$ hitung < $\mathrm{F}$ tabel, maka $\mathrm{H} 0$ diterima, berarti masing-masing variabel bebas secara bersama-sama tidak mempunyai pengaruh yang signifikansi terhadap variabel terikat.

\section{Koefisien Determinan $\left(R^{2}\right)$}

Koefisien Determinasi (R2) pada intinya mengukur seberapa jauh kemampuan model dalam menerangkan variasi variabel dependen (Ghozali, 2009).Nilai koefisien determinasi adalah antara nol dan satu. Nilai R2 yang terkecil berarti kemampuan variabelvariabel independen dalam menjelaskan variasi variabel dependen sangat terbatas.Nilai yang mendekati satu berarti variabel-variabel independen memberikan hampirsemua informasi yang dibutuhkan untuk memprediksi variasi variabel dependen. 
HASIL DAN PEMBAHASAN

Tanggapan Responden terhadap Jurusan, Biaya, Kualitas dan Keputusan Siswa pada SMK Negeri 2 Batanghari

Berdasarkan hasil pengolahan data dengan persentase rata - rata dari 5 aspek penilaian yang diteliti menunjukkan hasil indeks tertinggi sebesar 3,64 untuk pernyataan SMK Negeri 2 Batanghari telah menentukan Jurusan sesuai dengan bakat yang dimiliki calon siswa dan yang terendah sebesar 3,43 untuk pernyataan SMK Negeri 2 Batanghari memberikan kesempatan kepada calon siswa untuk memilih jurusan sesuai minat/keinginan peserta dengan rata - rata indeks sebesar 3,55 yang berarti jurusan pada SMK Negeri 2 Batanghari berada dalam kategori Baik. Untuk Biaya, dari 6 aspek penilaian yang diteliti didapat indeks tertinggi adalah 3,55 untuk pernyataan SMK Negeri 2 Batanghari membebaskan biaya komite bagi siswa dan yang terendah adalah 3,30 untuk pernyataan SMK Negeri 2 Batanghari berada dekat dengan pusat kota sehingga biaya transportasi cukup murah. Sedangkan rata - rata indeks sebesar 3,41 yang berarti bahwa dilihat dari kategori biaya untuk masuk SMK Negeri 2 Batanghari tergolong Murah. Hasil penelitian untuk aspek kualitas didapat nilai indeks tertinggi sebesar 3,64 untuk pernyataan SMK Negeri 2 Batanghari memiliki fasilitas sekolah cukup baik meliputi bengkel kerja dan fasilitas pendukung lainnya demi keberhasilan siswa dan indeks terendah sebesar 3,28 untuk pernyataan Proses belajar di SMK Negeri 2 Batanghari lebih baik untuk membangun dan mengembangkan potensi siswa. Sedangkan rata - rata indeks sebesar 3,48 yang menunjukan bahwa kualitas SMK Negeri 2 Batanghari berada dalam kategori Baik. Sedangkan untuk penelitian Keputusan Siswa untuk masuk SMK Negeri 2 Batanghari didapat rata-rata indeks sebesar 3,52 yang berarti bahwa minat siswa untuk masuk SMK Negeri 2 Batanghari berada dalam kategori Baik.

Pengaruh Jurusan, Biaya dan Kualitas terhadap Keputusan Siswa untuk masuk SMK Negeri 2 Batanghari Uji validitas

Tabel 2. Hasil pengujian validitas

\begin{tabular}{|c|c|c|c|c|c|}
\hline No & Variabel & Item & $\begin{array}{c}\text { Korelasi } \\
\text { Product moment } \\
\left(\mathrm{r}_{\text {hitung }}\right)\end{array}$ & $\begin{array}{c}\mathrm{r}_{\text {tabel }} \\
\mathrm{a}=0,05 \\
\mathrm{~N}=110 .\end{array}$ & KET \\
\hline \multirow[t]{5}{*}{1.} & JURUSAN $\left(\mathrm{X}_{1}\right)$ & $\mathrm{X}_{1 . \mathrm{P} 1}$ & 0.418 & 0,1857 & Valid \\
\hline & & $\mathrm{X}_{1 . \mathrm{P} 2}$ & 0.660 & 0,1857 & Valid \\
\hline & & $\mathrm{X}_{1 . \mathrm{P} 3}$ & 0.576 & 0,1857 & Valid \\
\hline & & $\mathrm{X}_{1 . \mathrm{P} 4}$ & 0.304 & 0,1857 & Valid \\
\hline & & $\mathrm{X}_{1 . \mathrm{P} 5}$ & 0.261 & 0,1857 & Valid \\
\hline \multirow[t]{6}{*}{2.} & BIAYA $\left(X_{2}\right)$ & $\mathrm{X}_{2 . \mathrm{P} 1}$ & 0.467 & 0,1857 & Valid \\
\hline & & $\mathrm{X}_{2 . \mathrm{P} 2}$ & 0.687 & 0,1857 & Valid \\
\hline & & $\mathrm{X}_{2 . \mathrm{P} 3}$ & 0.707 & 0,1857 & Valid \\
\hline & & $\mathrm{X}_{2 . \mathrm{P} 4}$ & 0.209 & 0,1857 & Valid \\
\hline & & $\mathrm{X}_{2 . \mathrm{P} 5}$ & 0.357 & 0,1857 & Valid \\
\hline & & $\mathrm{X}_{2 . \mathrm{P} 6}$ & 0.707 & 0,1857 & Valid \\
\hline \multirow[t]{6}{*}{3.} & KUALITAS $\left(\mathrm{X}_{3}\right)$ & $\mathrm{X}_{3 . P 1}$ & 0.393 & 0,1857 & Valid \\
\hline & & $\mathrm{X}_{3 . \mathrm{P} 2}$ & 0.771 & 0,1857 & Valid \\
\hline & & $\mathrm{X}_{3 . \mathrm{P} 3}$ & 0.718 & 0,1857 & Valid \\
\hline & & $\mathrm{X}_{3 . \mathrm{P} 4}$ & 0.464 & 0,1857 & Valid \\
\hline & & $\mathrm{X}_{3 . \mathrm{P} 5}$ & 0.734 & 0,1857 & Valid \\
\hline & & $\mathrm{X}_{3 . \mathrm{P} 6}$ & 0.698 & 0,1857 & Valid \\
\hline \multirow[t]{9}{*}{4.} & KEPUTUSAN SISWA (Y) & $\mathrm{Y}_{1}$ & 0.309 & 0,1857 & Valid \\
\hline & & $\mathrm{Y}_{2}$ & 0.390 & 0,1857 & Valid \\
\hline & & $\mathrm{Y}_{3}$ & 0.407 & 0,1857 & Valid \\
\hline & & $\mathrm{Y}_{4}$ & 0.279 & 0,1857 & Valid \\
\hline & & $\mathrm{Y}_{5}$ & 0.384 & 0,1857 & Valid \\
\hline & & $\mathrm{Y}_{6}$ & 0.355 & 0,1857 & Valid \\
\hline & & $\mathrm{Y}_{7}$ & 0.188 & 0,1857 & Valid \\
\hline & & $\mathrm{Y}_{8}$ & 0.386 & 0,1857 & Valid \\
\hline & & $\mathrm{Y}_{9}$ & 0.331 & 0,1857 & Valid \\
\hline
\end{tabular}

Sumber : data primer yang diolah. (SPSS 22.00)

Tabel menunjukan bahwa semua indikator yang digunakan untuk mengukur variabel-variabel pada penelitian ini memiliki nilai koefisien korelasi yang lebih besar dari $\mathrm{r}_{\text {tabel }}(0,1857$ ). Jadi dapat disimpulkan semua indikator tersebut adalah valid.

\section{Uji Reliabilitas}

Uji reliabilitas merupakan uji yang menunjukan sejauh mana alat ukur dapat dipercaya dan dapat diandalkan untuk diteliti. Dalam melaksanakn uji ini peneliti melakukan perhitungan dengan menggunkan bantuan program SPSS 22.0. 
Tabel 3. Hasil Pengujian Reliabelitas

\begin{tabular}{clccc}
\hline No & \multicolumn{1}{c}{ Variabel } & $\begin{array}{c}\text { Cronbach's } \\
\text { Alpha }\end{array}$ & $\begin{array}{c}\text { Taraf } \\
\text { Signifikan }\end{array}$ & Ket. \\
\hline 1. & Jurusan (x1) & 0.721 & 0,600 & Reliabel \\
2. & Biaya (x2) & 0.747 & 0,600 & Reliabel \\
3. & Kualitas (x3) & 0.775 & 0,600 & Reliabel \\
4. & Keputusan & 0.677 & 0,600 & Reliabel \\
& Siswa (Y) & & & \\
\hline
\end{tabular}

Sumber : data primer yang diolah. (SPSS 22.00)
Teknik pengujian reliabelitas menggunakan cronbach's alpha. Hasil pengujian menunjukan bahwa nilai cronbach's alpha lebih besar dari taraf signifikan 0,600 , artinya semua pernyataan dalam penelitian ini dapat dikatakan reliabel.

\section{Regresi Linier berganda}

Berdasarkan hasil analisis yang dihitung dengan menggunakan program SPSS 22.00 for windows dapat disusun ringkasan hasil analisis regresi linier berganda sebagai berikut.

Tabel 4. Hasil Regresi Linier Berganda

\begin{tabular}{|c|c|c|c|c|c|c|}
\hline \multirow{2}{*}{\multicolumn{2}{|c|}{ Model }} & \multicolumn{2}{|c|}{ Unstandardized Coefficients } & \multirow{3}{*}{\begin{tabular}{|l} 
Standardized Coefficients \\
Beta \\
\end{tabular}} & \multirow{3}{*}{\begin{tabular}{|l}
$\mathrm{t}$ \\
.294
\end{tabular}} & \multirow{3}{*}{\begin{tabular}{|l} 
Sig. \\
.769
\end{tabular}} \\
\hline & & & \multirow{2}{*}{\begin{tabular}{|l} 
Std. Error \\
1.822
\end{tabular}} & & & \\
\hline 1 & (Constant) & & & & & \\
\hline & $\mathrm{x} 1$ & .664 & .074 & .446 & 8.973 & .000 \\
\hline & $\mathrm{x} 2$ & .562 & .051 & .545 & 10.969 & .000 \\
\hline & x3 & .375 & .045 & .415 & 8.396 & .000 \\
\hline
\end{tabular}

Sumber : daya primer yang diolah. (SPSS 22.00)

Dari tabel diatas didapat persamaan regresi linier berganda, yaitu sebagai berikut :

$Y=0,536+0,664 X_{1}+0,562 X_{2}+0,375 X_{3}$

1. Konstanta (a) sebesar 0,536 berarti bahwa apabila Jurusan $\left(\mathrm{X}_{1}\right)$, Biaya $\left(\mathrm{X}_{2}\right)$, dan Kualitas $\left(\mathrm{X}_{3}\right)$ diasumsikan $=0$, maka Keputusan Siswa $(Y)$ bernilai sebesar 0,536.

2. Koefisien regresi variabel Jurusan $\left(X_{1}\right)$ sebesar 0,664 memberikan arti bahwa setiap kenaikan variabel jurusan sebesar satu satuan akan mempengaruhi keputusan siswa untuk masuk SMK Negeri 2 Batanghari sebesar 0,664 dengan asumsi variabel lain tetap.

3. Koefisien regresi variabel Biaya $\left(\mathrm{X}_{2}\right)$ sebesar 0,562 memberikan arti bahwa setiap kenaikan variabel Biaya sebesar satu satuan akan mempengaruhi keputusan siswa untuk masuk SMK Negeri 2 Batanghari sebesar 0,0562 dengan asumsi variabel lain tetap. dan

4. Koefisien regresi variabel Kualitas $\left(\mathrm{X}_{3}\right)$ sebesar 0,375 memberikan arti bahwa setiap kenaikan variabel Kualitas sebesar satu satuan akan mempengaruhi keputusan siswa untuk masuk SMK Negeri 2 Batanghari sebesar 0,375 dengan asumsi variabel lain tetap.

\section{Uji Parsial (Uji t)}

Untuk menguji variabel Jurusan (X1), Biaya (X2), dan Kualitas (X3) mempunyai pengaruh terhadap keputusan siswa (Y), maka dalam penelitian ini melihat besar masing-masing koefisien regresi dari variabel independen. Adapun signifikasi dari masing-masing koefisien itu di uji dengan menggunakan uji parsial t-test dan didapat hasil sebagai berikut :

1. Jurusan $(\mathrm{X} 1), \mathrm{t}_{\text {hitung }}(8,973)>\mathrm{t}_{\text {tabel }}(1,65936)$ dan angka signifikan sebesar (sig.) $0,000<$ dari level signifikansi $a=0,05(5 \%)$, dimana $\mathrm{H}_{0}$ ditolak $\mathrm{H}_{\mathrm{a}}$ diterima. Jadi, dapat disimpulkan bahwa Jurusan mempunyai pengaruh signifikan terhadap keputusan siswa.

2. Biaya (X2), $t_{\text {hitung }}(10,969)>t_{\text {tabel }}(1,65936)$ dan angka signifikan sebesar (sig.) $0,000<$ dari level signifikansi $a=0,05(5 \%)$, dimana $\mathrm{H}_{0}$ ditolak $\mathrm{H}_{\mathrm{a}}$ diterima. Jadi, dapat disimpulkan bahwa Biaya mempunyai pengaruh signifikan terhadap keputusan siswa.

3. Kualitas (X3), $t_{\text {hitung }}(8,396)>t_{\text {tabel }}(1,65936)$ dan angka signifikan sebesar (sig.) $0,000<$ dari level signifikansi $\mathrm{a}=0,05(5 \%)$, dimana $\mathrm{H}_{0}$ ditolak $\mathrm{H}_{\mathrm{a}}$ diterima. Jadi, dapat disimpulkan bahwa kualitas mempunyai pengaruh signifikan terhadap keputusan siswa.

\section{Uji Simultan (Uji F)}


Tabel 5. ANOVA

\begin{tabular}{|l|c|c|c|c|c|}
\hline \multicolumn{1}{|c|}{ ANOVA $^{\mathbf{b}}$} \\
\hline Model & Sum of Squares & Df & Mean Square & F & Sig. \\
\hline Regression & 651.881 & 3 & 217.294 & 101.212 & $.000^{\mathrm{a}}$ \\
\hline Residual & 227.574 & 106 & 2.147 & & \\
\hline Total & 879.455 & 109 & & & \\
\hline
\end{tabular}

a. Predictors: (Constant), $\mathrm{x} 3, \mathrm{x} 1, \mathrm{x} 2$

b. Dependent Variable: $y$

Sumber : data primer yang diolah. (SPSS 22.00)

Dari hasil perhitungan statistik uji $\mathrm{F}$ pada tabel ANOVA diperoleh nilai f hitug sebesar 101,212 dengan tingkat signifikan 0,000 serta df 3 (106) dan nilai f tabel sebesar 2,69. Hal ini menunjukan bahwa nilai f hitung lebih dari $\mathrm{f}$ tabel. Artinya secara bersama-sama Jurusan,
Biaya dan Kualitas berpengaruh terhadap Keputusan Siswa untuk masuk SMK Negeri 2 Batanghari $(101,212$ $>2,69$ ).

\section{Koefisien Determinasi $\left(R^{2}\right)$}

Tabel 6. Model Summary

\begin{tabular}{|c|c|c|c|c|c|c|c|c|c|c|}
\hline \multicolumn{11}{|c|}{ Model Summary ${ }^{b}$} \\
\hline \multirow[b]{2}{*}{ Model } & \multirow[b]{2}{*}{$\mathrm{R}$} & \multirow[b]{2}{*}{ R Square } & \multirow[b]{2}{*}{ Adjusted R Square } & \multirow{2}{*}{$\begin{array}{l}\text { Std. Error of the } \\
\text { Estimate }\end{array}$} & \multicolumn{5}{|c|}{ Change Statistics } & \multirow{2}{*}{$\begin{array}{l}\text { Durbin- } \\
\text { Watson }\end{array}$} \\
\hline & & & & & $\begin{array}{l}\text { R Square } \\
\text { Change }\end{array}$ & F Change & df1 & df 2 & $\begin{array}{l}\text { Sig. F } \\
\text { Change }\end{array}$ & \\
\hline 1 & $.861^{2}$ & .741 & .734 & 1.465 & .741 & 101.212 & 3 & 106 & .000 & 1.564 \\
\hline \multicolumn{11}{|c|}{ a. Predictors: (Constant), $\mathrm{x} 3, \mathrm{x} 1, \mathrm{x} 2$} \\
\hline \multicolumn{3}{|c|}{ b. Dependent Variable: y } & & & & & & & & \\
\hline
\end{tabular}

sumber : data primer yang diolah. (SPSS 22.00)

Dari tabel $\mathrm{d}$ iatas terlihat bahwa angka Adjust $\mathrm{R}$ Square yang dihasilkan sebesar 0,734 jadi dapat disimpulkan persentase pengaruh Jurusan, Biaya dan Kualitas terhadap Keputusan Siswa untuk masuk di SMK Negeri 2 Batanghari sebesar 73,4\% dan sisanya $26,6 \%$ dipengaruh oleh faktor lain yang tidak diteliti dalam penelitian ini.

\section{SIMPULAN}

Berdasarkan hasil penelitian dan pembahsaan yang telah di uraikan, maka dapat ditarik kesimpulan bahwa ditinjau dari segi Jurusan, Biaya dan Kualitas berada dalam kategori baik begitu juga dengan minat siswa (keputusan) untuk masuk SMK Negeri 2 Batanghari. Sedangkan untuk Pengaruh Jurusan (X1), Biaya (X2), Dan Kualitas (X3) terhadap keputusan siswa untuk masuk SMK Negeri 2 Batanghari dari hasil uji Uji t diketahui bahwa variabel independen yang paling dominan atau memberikan pengaruh yang positif adalah variabel Biaya (X2) dengan $t_{\text {hitung }}(10,969)>t_{\text {tabel }}$ $(1,65936)$ dengan signifikasi sebesar (sig.) $0,000<$ dari level signifikasi $a=0,05(5 \%)$. Untuk Uji F Diketahui $F_{\text {hitung }}=101,212>F_{\text {tabel }}=2,69$ Artinya secara bersamasama Jurusan, Biaya dan Kualitas berpengaruh terhadap Keputusan Siswa di SMK Negeri 2 Batanghari serta berdasarkan Uji Determinasi diketahui bahwa variabel Jurusan (X1), Biaya (X2), Dan Kualitas (X3) mempunyai pengaruh sebesar $73,4 \%$ terhadap keputusan siswa dan masih ada sebesar $26,6 \%$ yang ditentukan oleh faktor lain untuk penelitian lebih lanjut.

\section{DAFTAR PUSTAKA}

Basu Swastha dan Irawan 2000, Manajamen Pemasaran Modern, Edisi Kedua, Liberty, Yogyakarta, Skripsi Adi Susandi 2014, Muara Bulian, STIEGK.

http://ahmadsayipulloh9gkece.

blogspot.com/2014/03/memilih-sekolah-lanjutansetelah-lulus_7.html

http://budiana2014.blogspot.com/2015/10/indikatorpemilihan-studi-lanjut-ke-sma.html

http://edukasi.kompasiana.com/2009/12/16/apakahminat-itu/).

http://www.kompasiana.com/dhaniapriandigreg/apakahjurusan-dan-program-studiitu_552e2b8c6ea83497148b456c

http://www.kamuskbbi.id/kbbi/artikata.php?mod=view\& Jurusan\&id=34104-kamus-inggris-indonesia.html

http://litbang.kemdikbud.go.id/data/bansm/Pedoman Akreditasi BAN

https://tulisanterkini.com/artikel/artikel-ilmiah/9165faktor-faktor-yang-mempengaruhi-persepsi.html http://41816010007.blog.mercubuana.ac.id/?p=9 
Hutagaol Yudicium R.M. 2009. Minat dan Motivasi Siswa Memilih Sekolah Menengah Kejuruan (SMK) Mendorong Peningkatan Mutu Pendidikan di Kabupaten Tapanuli Utara. Tesis Universitas Sumatera Utara Medan. http://www.researchgate.net/publication/4234878 6. Diakses tanggal 8 Desember 2013. Hal 21-26 (http://konsling.blogspot.com /2012/07/ memilihsekolah-lanjutan-setelah-smp.html).

Imam Ghazali, 2009, Desain Penelitian Kuantitatif dan Kualitatif Akuntansi, Bisnis dan Ilmu Sosial Lainnya

Philip Kotler, Kevin Lane Keller, Manajemen Pemasaran, Edisi 13 Jilid 1, Alih Bahasa, Bob Sabran, (Erlangga: Jakarta, 2008), 166.

Setiawan. 2012. Pengertian dan Definisi Metode, Penelitian dan metode penelitian.

Silalahi Ulber. 2010. Metode Penelitian Sosial. Bandung PT. Refika Aditama.

Sugiyono. 2011. Metode Penelitian Kuantitatif, Kualitatif dan $R \& D$. Bandung: Alfabeta.

Suharsimi Arikunto. 2010. Prosedur Penelitian Suatu pendekatan praktik. Jakarta: PT. Rineka Citra.

Tim Penyusun. 2015. Buku Panduan Penelitian Dosen. Muara Bulian : STIE-GK. 